\title{
Investigating the Urease Activity of Sporosarcina pasteurii for Potential Usage of Microbially Induced Calcium Carbonate Precipitation
}

\author{
Kağan Eryürük* \\ * Necmettin Erbakan University, Faculty of Engineering, Departmant of Civil Engineering, Konya, Turkey, (ORCID: 0000-0003-3993-839X), \\ kaganeryuruk@gmail.com
}

(2nd International Conference on Applied Engineering and Natural Sciences ICAENS 2022, March 10-13, 2022)

(DOI: 10.31590/ejosat.1061497)

\begin{abstract}
ATIF/REFERENCE: Eryürük, K. (2022). Investigating the urease activity of Sporosarcina pasteurii for potential usage of microbially induced calcium carbonate precipitation. European Journal of Science and Technology, (34), 1-4.
\end{abstract}

\begin{abstract}
The urease activity of Sporosarcina pasteurii was investigated using different number of bacterial cells. Resting Sporosarcina pasteurii cells and $500 \mathrm{mM}$ urea solution were placed into the beakers to measure the change in electrical conductivity of the solution. The electrical conductivity values were varied between $0.382 \mathrm{mS} / \mathrm{m}$ and $6.224 \mathrm{mS} / \mathrm{m}$ for $10 \mathrm{~min}$. The highest electrical conductivity was measured for addition of the largest number of cells $\left(10^{*} 10^{9}\right)$ to the solution. Resting Sporosarcina pasteurii cells and $500 \mathrm{mM}$ urea and $500 \mathrm{mM} \mathrm{CaCl}_{2}$ solution were also placed into the beakers to observe and evaluate microbially induced $\mathrm{CaCO}_{3}$ precipitation. The amount of microbially induced $\mathrm{CaCO}_{3}$ precipitation was changed between $4 \mathrm{mg}$ and $28 \mathrm{mg}$ in the experiments for ten minutes. The highest amount of $\mathrm{CaCO}_{3}$ precipitation was observed in beaker with the highest number of cells $(28 \mathrm{mg})$ than in those with the smallest number of cells $(4 \mathrm{mg})$. Hence, the amount of microbially induced $\mathrm{CaCO}_{3}$ precipitation was increased in direct proportion to the cell number in the beakers. The experiments suggest that the urease activity $S$. pasteurii is depended on the number of cells and more cells of $S$. pasteurii leads more microbially induced $\mathrm{CaCO}_{3}$ precipitation in a short time period.
\end{abstract}

Keywords: Electrical conductivity, Microbially induced calcium carbonate precipitation, Number of cells, Sporosarcina pasteurii, Urease activity.

\section{Mikrobiyal Olarak İndüklenen Kalsiyum Karbonat Çökeltisinin Potansiyel Kullanımı için Sporosarcina pasteurii' nin Üreaz Aktivitesinin Araştırılması}

Öz

Sporosarcina pasteurii'nin üreaz aktivitesi, farklı sayıda bakteri hücresi kullanılarak araştırıldı. Çözeltinin elektriksel iletkenliğindeki değişimi ölçmek için dinlenme halindeki Sporosarcina pasteurii hücreleri ve $500 \mathrm{mM}$ üre çözeltisi beherlere eklendi. Elektriksel iletkenlik değerleri 10 dakika süreyle $0.382 \mathrm{mS} / \mathrm{m}$ ile $6.224 \mathrm{mS} / \mathrm{m}$ arasında değişiklik göstermiştir. En yüksek elektriksel iletkenlik, çözeltiye en fazla sayıda hücrenin $\left(10^{*} 10^{9}\right)$ eklenmesi için ölçülmüştür. Dinlenme halindeki Sporosarcina pasteurii hücreleri ve 500 $\mathrm{mM}$ üre ve $500 \mathrm{mM} \mathrm{CaCl}$ çözeltisi de mikrobiyal olarak indüklenen $\mathrm{CaCO}_{3}$ çökeltisini gözlemlemek ve değerlendirmek için beherlere yerleştirildi. On dakikalık deneylerde mikrobiyal olarak indüklenen $\mathrm{CaCO}_{3}$ çökeltisi miktarı $4 \mathrm{mg}$ ile $28 \mathrm{mg}$ arasında ölçülmüştür. En yüksek $\mathrm{CaCO}_{3}$ çökeltisi miktarı, en az hücre sayısına $(4 \mathrm{mg})$ kıyasla en fazla hücre sayısına sahip beherde $(28 \mathrm{mg})$ gözlendi. Bu nedenle, mikrobiyal olarak indüklenen $\mathrm{CaCO}_{3}$ çökeltisi miktarının, beherlerdeki hücre sayısıyla doğru orantılı olarak arttığı söylenebilir. Deneyler, S. pasteurii'nin üreaz aktivitesinin hücre sayısına bağlı olduğunu ve daha fazla $S$. pasturii hücresinin kısa bir süre içinde daha fazla mikrobiyal olarak indüklenen $\mathrm{CaCO}_{3}$ çökeltisine yol açabileceğini göstermektedir.

Anahtar Kelimeler: Elektriksel iletkenlik, Hücre sayısı, Mikrobiyal olarak indüklenen $\mathrm{CaCO}_{3}$ çökeltisi, Sporosarcina pasteurii, Üreaz aktivitesi.

* Corresponding Author: kaganeryuruk@gmail.com 


\section{Introduction}

Microbially induced calcium carbonate has been studied by many researchers to develop biotechnology methods such as improving construction materials [1], decreasing hydraulic conductivity of porous media [2], changing soil properties [3-5] increasing oil recovery [6] because of widespread presence of ureolytic bacteria in the environment. Although there are a number of species which produce $\mathrm{CaCO}_{3}$ minerals, Sporosarcina pasteurii was used by many researchers widely and there are numerous reports on bacterial $\mathrm{CaCO}_{3}$ precipitation by $S$. pasteurii [7-12] because $S$. pasteurii is not a pathogenic bacterium, it is not suppressed by ammonium, and it provides high urease [2].

$S$. pasteurii produces urease which result in urea hydrolysis and this hydrolysis causes ammonia and carbon dioxide [2]. The ammonia gives rise increasing $\mathrm{pH}$ of the ambience and, which in turn induces calcite precipitation in calcium rich environment. The hydrolysis of urea in a solution with calcium chloride was used in the researches mostly [13-14]. The reaction steps and overall reaction can be identified as [4];

$$
\begin{aligned}
& \mathrm{NH}_{2} \mathrm{CONH}_{2}+\mathrm{H}_{2} \mathrm{O} \stackrel{\text { urease }}{\longrightarrow} 2 \mathrm{NH}_{3}+\mathrm{CO}_{2} \\
& 2 \mathrm{NH}_{3}+2 \mathrm{H}_{2} \mathrm{O} \rightarrow 2 \mathrm{NH}_{4}^{+}+2 \mathrm{OH}^{-} \\
& \mathrm{CO}_{2}+\mathrm{OH}^{-} \rightarrow \mathrm{HCO}_{3}^{-} \\
& \mathrm{CaCl}_{2} \rightarrow \mathrm{Ca}^{2+}+2 \mathrm{Cl}^{-} \\
& \mathrm{Ca}^{2+}+\mathrm{HCO}_{3}^{-}+\mathrm{HCO}_{3}^{-} \rightarrow \mathrm{CaCO}_{3}+\mathrm{H}_{2} \mathrm{O}
\end{aligned}
$$

Overall reaction:

$\mathrm{NH}_{2} \mathrm{CONH}_{2}+\mathrm{CaCl}_{2}+2 \mathrm{H}_{2} \mathrm{O} \rightarrow 2 \mathrm{NH}_{4}^{+}+2 \mathrm{Cl}^{-}+\mathrm{CaCO}_{3}(6)$

To understand the potential usage of microbially induced calcium carbonate precipitation (MICCP), urease activity of $S$. pasteurii needs to be identified. Therefore, the amount of MICCP was measured and the relationship between cell concentration and change in electrical conductivity of urea solution was investigated using different number of cells of $S$. pasteurii in present study.

\section{Material and Method}

\subsection{Microorganism used in the experiments and culturing}

S. pasteurii [American Type Culture Collection (ATCC) 11859] was used as microorganism to evaluate urease activity of cells. The medium (Tris-YE) for cultures consisted of Tris buffer, $130 \mathrm{mM}$ (pH 9.0); $\left(\mathrm{NH}_{4}\right)_{2} \mathrm{SO}_{4}, 10 \mathrm{~g}$; and yeast extract, $20 \mathrm{~g}$; to which $2 \%$ agar per liter of pure water was used for solid medium which was used for culturing. Autoclave at $121^{\circ} \mathrm{C}$ for $15 \mathrm{~min}$ was used for sterilization of medium elements [2].

$1 \mathrm{~L}$ Tris-YE medium was used to obtain culture of $S$. pasteurii [2]. $30^{\circ} \mathrm{C}$ and $120 \mathrm{rpm}$ shaking were employed for overnight for the culture. The bacterial cells were harvested using centrifuge at $10000 * \mathrm{~g}$ for $10 \mathrm{~min}$ and rinsed with pure water two times [2]. Eventually, S. pasteurii cells were dissolved again into $100 \mathrm{~mL}$ pure water to obtain an optical density of 2.25 (abbreviated as $\mathrm{OD}_{600} 2.25$ ) at $600 \mathrm{~nm}$. $\mathrm{OD}_{600} 2.25$ was corresponded $10^{9}$ cells $/ \mathrm{mL}$. Resting $S$. pasteurii cells were used in the experiments.

\subsection{Experimental setup and conditions}

Batch experiments were carried out at $22^{\circ} \mathrm{C}$ as constant temperature. The electrical conductivity of the solution was measured because the amount of urea hydrolyzed can be related to the production of ammonium. Two moles of ammonium $\left(\mathrm{NH}_{4}^{+}\right)$ is released while the hydrolysis of 1 mole of urea occurs. The electrical conductivity of the solution was increased because of the hydrolysis reaction. The concentration of urea hydrolyzed and change in electrical conductivity of the solution was identified as [15]:

$\operatorname{Urea}(m M)=\Delta$ Electrical conductivity $\left(\frac{m S}{m}\right) * 0.1111$

$50 \mathrm{~mL}$ of urea solution $(500 \mathrm{mM})$ was filtered using a 0.22 $\mu \mathrm{m}$ filter for sterilization and poured into $100 \mathrm{~mL}$ beakers. $1 \mathrm{~mL}$, $2 \mathrm{~mL}, 4 \mathrm{~mL}, 8 \mathrm{~mL}$, and $10 \mathrm{~mL}$ cell suspensions, which were corresponded to $10^{9}$ cells, $2 * 10^{9}$ cells, $4 * 10^{9}$ cells, $8^{*} 10^{9}$ cells, and $10 * 10^{9}$ cells of $S$. pasteurii, respectively, were added to the beakers. Finally, the bacterial cells were added to the beakers.

A magnetic stirrer was employed to provide the humogen cell suspension in the beakers. The initial electrical conductivity of all solutions was measured using conductivity meter and noted. Then, the change in electrical conductivity of all solutions was measured for each minute for 10 minutes. The electrical conductivity value for each experiment was calculated by subtracting the initial value from the final value.

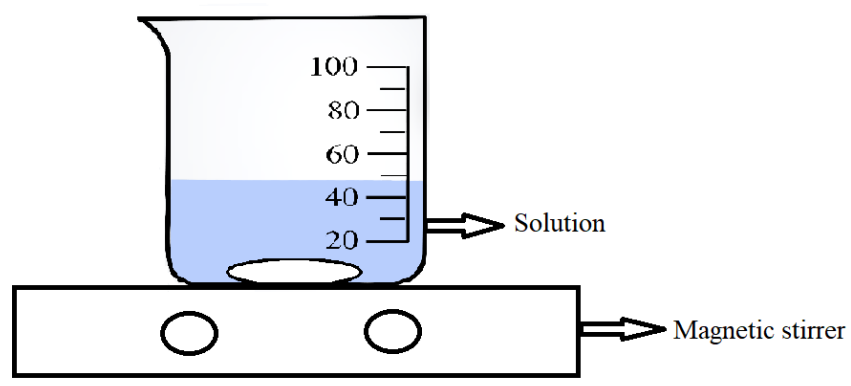

Figure 1. Experimental setup

To obtain MICCP, $50 \mathrm{~mL}$ of $500 \mathrm{mM}$ urea and $500 \mathrm{mM} \mathrm{CaCl}_{2}$ solution (precipitation solution) was also filtered using a $0.22 \mu \mathrm{m}$ filter for sterilization and poured into $100 \mathrm{~mL}$ beaker. $1 \mathrm{~mL}, 2 \mathrm{~mL}$, $4 \mathrm{~mL}, 8 \mathrm{~mL}$, and $10 \mathrm{~mL}$ cell suspensions were added to the precipitation solution for 10 minutes. After $10 \mathrm{~min}$, the reaction was stopped using $\mathrm{N}$-(n-butyl) thiophosphoric triamide as inhibitor. After that, $0.1 \mathrm{~N} \mathrm{HNO}_{3}$ was used to dissolve $\mathrm{CaCO}_{3}$ formed in the beakers. The specimens were prepared to measure calcium concentration using ICP-AES (inductively coupled plasma atomic emission spectroscopy). When the measurements were completed using ICP-AES, the amount of $\mathrm{CaCO}_{3}$ which had formed into the beakers was computed. 


\section{Results and Discussion}

The initial electrical conductivity value was measured as $0.253 \mathrm{mS} / \mathrm{m}$. After adding different number of cells to the solutions, the urease activity was observed beginning from the first minute to the tenth minute.

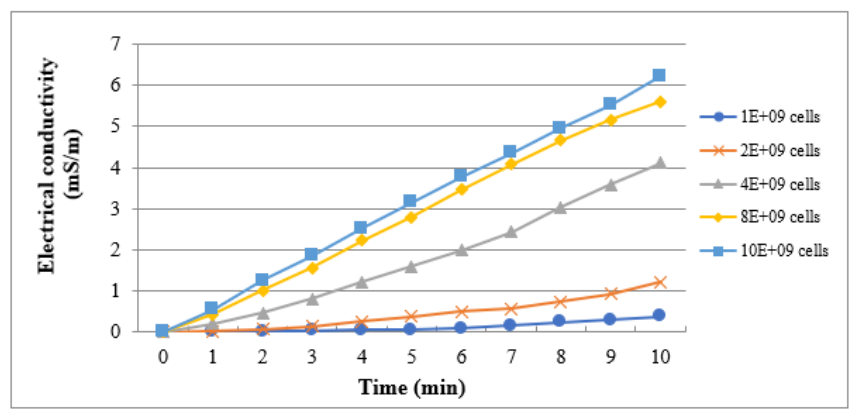

Figure 2. The change in electrical conductivity for different number of cells in time

The electrical conductivity values were changed between $0.07 \mathrm{mS} / \mathrm{m}$ and $0.547 \mathrm{mS} / \mathrm{m}$ for the range of $10^{9}$ cells and $10^{*} 10^{10}$ cells, respectively, in the first minute (Fig. 2). The electrical conductivity values were increased in time for all conditions. The highest electrical conductivity was measured as $6.224 \mathrm{mS} / \mathrm{m}$ for addition of $10^{*} 10^{9}$ cells to the solution for $10 \mathrm{~min}$. As indicated figure 2 , the electrical conductivity had closer values for $10^{9}$ cells and $2 * 10^{9}$ cells, and for $8 * 10^{9}$ cells and $10^{*} 10^{9}$ cells for $10 \mathrm{~min}$. The increase in number of cells in the solution was resulted in high rate of hydrolysis. Hence, it can be said that the electrical conductivity was increased depending on cell numbers added to the solution.

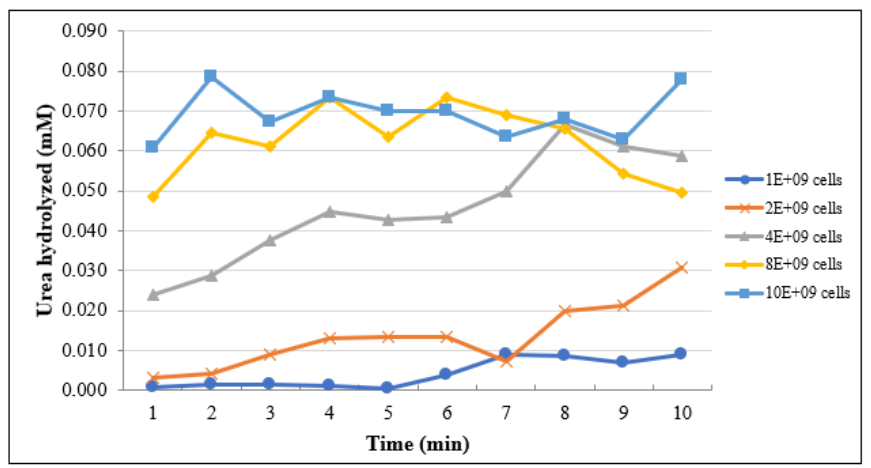

Figure 3. The change in concentration of urea hydrolized for different number of cells in time

In the presence of $10 * 10^{9}$ cells, the concentration of urea hydrolyzed, which was the highest value, was $0.078 \mathrm{mM}$ urea after ten minutes. The lowest concentration of urea hydrolyzed for ten minutes was measured as $0.009 \mathrm{mM}$ for $10^{9}$ cells added to the solution. As indicated in figure 3, all conditions have urease activity from the first minute of the experiment. However, the urease activity was reduced when $10^{9}$ cells was added to the solution. As shown in figure 3 , increase in number of cells was resulted in rise of the concentration of urea hydrolyzed. Thus, it can be said that when there is no nutrient to enhance the number

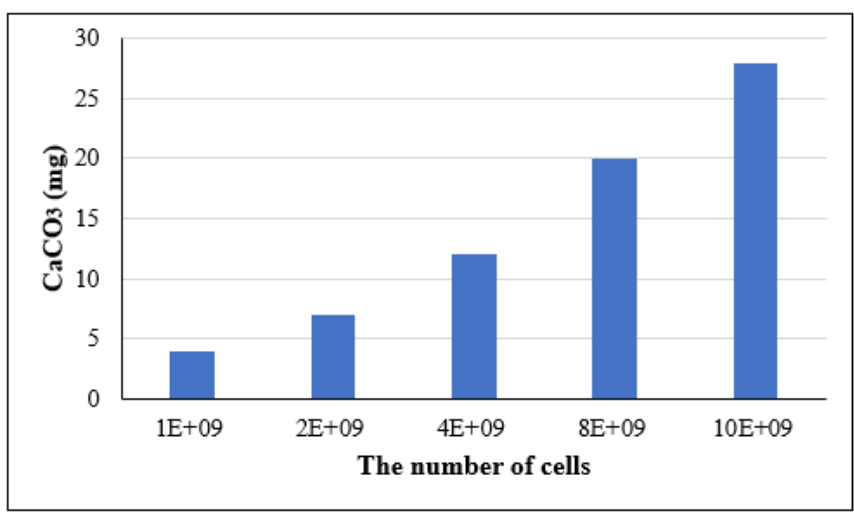

Figure 4. The amount of $\mathrm{CaCO}_{3}$ precipitated

The range of the amount of $\mathrm{CaCO}_{3}$ precipitation was calculated between $4 \mathrm{mg}$ and $28 \mathrm{mg}$ as shown in figure 4 . The greatest amount of $\mathrm{CaCO}_{3}$ for $S$. pasteurii was achieved (28 mg) when the bacteria concentration of $10^{*} 10^{9}$ cells was added to the precipitation solution. Previous studies agreed producing large amounts of urease enzyme in the presence of urea [16-17] and, ultimately, the higher concentration of $\mathrm{CO}_{3}{ }^{2-}$ were released and bound to the more concentration of $\mathrm{Ca}^{2+}$ to form MICCP.

\section{Conclusions and Recommendations}

In this study, urease activity of resting $S$. pasteurii cells was investigated. The results were indicated that highest urease activity was achieved when the number of cells was $10 * 10^{9}$, which was 10 times larger than the lowest number of cells used in the experiments. It should be noted that the urease activity $S$. pasteurii is depended on the number of cells.

The resting cells of $S$. pasteurii without nutrients to simulate the case of lack of nutrient in the environment. The effect of bacterial growth using nutrient sources such as yeast extract etc. should be examined to understand the potential usage of $S$. pasteurii for microbially induced calcium carbonate precipitation.

In summary, S. pasteurii has higher potential to precipitate amount of $\mathrm{CaCO}_{3}$. More cells of $S$. pasteurii leads more MICCP in a short time period. Therefore, time should be taking in consideration to apply MICCP technology.

of cells in the environment, high number of $S$. pasteurii cells could be used to get higher urease activity. 


\section{References}

[1] Ramachandran SK, Ramakrishnan V, Bang SS. Remediation of concrete using micro-organisms. ACI Mater J. 98(1):3-9, 2001.

[2] Eryürük, K., Yang, S., Suzuki, D., Sakaguchi, I., Akatsuka, T., Tsuchiya, T., and Katayama, A., Reducing hydraulic conductivity of porous media using $\mathrm{CaCO}_{3}$ precipitation induced by Sporosarcina pasteurii, Journal of Bioscience and Bioengineering, 119, 331-336, 2015.

[3] Whiffin VS, Van Paassen LA, Harkes MP. Microbial Carbonate Precipitation as a Soil Improvement Technique. Geomicrobiol J., 24:417-23, 2007.

[4] DeJong J. T., Mortensen B. M., Martinez B. C. and Nelson D. C. Bio-mediated soil improvement, Ecological Engineering, 36, 197-210, 2010.

[5] Chou C.-W., Seagren E. A., ASCE A. M., Aydilek A. H., ASCE M. and Lai M. Biocalcification of sand through ureolysis, Journal of Geotechnical and Geoenvironmental Engineering, Vol.137, No.12, 1179-1189, 2011.

[6] Wu J, Wang XB, Wang HF, Zeng RJ. Microbially induced calcium carbonate precipitation driven by ureolysis to enhance oil recovery. $R S C A d v .$, 7(59):37382-91, 2017.

[7] Ivanov Volodymyr and Chu Jian. Applications of microorganisms to geotechnical engineering for bioclogging abd biocementation of soil in situ, Rev.Environ. Sci. Biotechnol., 7, 139-153, 2008.

[8] Mitchell A. C. and Ferris F. G. The Influence of Bacillus pasteurii on the nucleation and growth of calcium carbonate, Geomicrobiology Journal, 23, 213-226, 2006.

[9] Tobler D. J., Cuthbert M. O., Greswell R. B., Siley M. S., Renshaw J. C., Handley-Sidhu S. and Phoenix V. R. Comparision of rates of ureolysis between $\mathrm{S}$. pasteurii and an indigenous groundwater community under conditions required to precipitate large volumes of calcite, Geochimica et Cosmochimica Acta , 75, 3290-3301, 2011.

[10] Stocks-Fischer S., Galinat J. K. and Bang S. S. Microbial precipitation of $\mathrm{CaCO} 3$, Soil Biology and Biochemistry, (31), 1563-1571, 1999.

[11] Al-Thawadi S. and Cord-Ruwisch R. (2012) Calcium carbonate crystals formation by ureolytic bacteria isolated from Australian soil and sludge, Journal of Advanced Science and Engineering, 2, 12-26, 2012.

[12] Mortensen B. M., Haber M. J., DeJong J. T., Caslake L. F. and Nelson D. C. Effects of environmental factors on microbial induced calcium carbonate precipitation, Journal of Applied Microbiology, 111, 338-349, 2011.

[13] Harkes M. P., Van Paassen L. A., Booster J. L., Whiffin V. S. and Van Loosdrecht M. C. M. Fixation and distribution of bacterial activity in sand to induce carbonate precipitation for ground reinforcement, Ecological Engineering, 36, 112$117,2010$.

[14] Okwadha G. D. O. and Li J. Optimum conditions for microbial carbonate precipitation, Chemosphere, 81, 11431148, 2010.

[15] Terzis, D., Laloui, L. 3-D micro-architecture and mechanical response of soil cemented via microbial-induced calcite precipitation. Sci Rep 8, 1416, 2018.

[16] Kaltwasser H., Kramer J., Conger W.R. Control of urease formation in certain aerobic bacteria. Arch. Microbiology, 81: 178-196, 1972.
[17] Friedrich B., Magasanik B. Urease of Klebsiella aerogenesis: control of its synthesis by glutamine synthetase. J. Bacteriol, 8: 313-322, 1977. 